УДК [7:908]:378.017.4

DOI:

Вікторія Прокопчук (Дикало), кандидат педагогічних наук, дочент кафедри гри на музичних інструментах Інституту мистецтв Рівненського державного гуманітарного університету

\title{
МИСТЕЦЬКЕ КРАЄЗНАВСТВО ЯК ЧИННИК НАЦІОАЛЬНО-ПАТРІОТИЧНОГО ВИХОВАННЯ МАЙБУТНІХ ПЕДАГОГІВ
}

У статті на основі аналізу й зіставлення наукових джерел і державних документів конкретизується зміст та структура понять "патріотизм”, "патріотичне виховання”, "національне виховання”, "національнопатріотичне виховання”, “національна самосвідомість”, “краєзнавство”, “мистецьке краєзнавство”, "музичне краєзнавство” у педагогічно-мистецькому контексті. Розкрито виховний потенціал краєзнавства, зокрема мистеиького, як засобу начіонально-патріотичного виховання майбутніх педагогів-музикантів. Доведено актуальність та доиільність введення авторського курсу "Музичне краєзнавство Рівненщини” до підготовки педагогів усіх мистецььких спещіальностей з огляду на запити суспільства та актуалізацію національно-патріотичного виховання.

Ключові слова: патріотизм; патріотичне виховання; національно-патріотичне виховання; національна самосвідомість; краєзнавство; музичне краєзнавство; мистеиьке краєзнавство.

Jim. 19.

Victoriya Prokopchuk (Dykalo), Ph. D.(Pedagogy), Associate Professor of the Playing Musical Instruments Department Rivne State University of Humanities

\section{MUSICAL LOCAL HISTORY AS A FACTOR OF NATIONAL PATRIOTIC EDUCATION OF FUTURE TEACHERS}

The purpose of the article is to analyze public documents about national patriotic education and theoretical pedagogical approaches to the point of essence and content of the terms "patriotism", "patriotic education", "national patriotic education", "national consciousness", "local history", "musical local history", "art local history". Identifying educational potential of art local history as a method of national patriotic education of future teachers of all artistic specialities is the objective of the article.

Methodology of the study is based on using of the set of theoretical methods: an analysis, systematization, comparison and synthesis. The terms "patriotism", "patriotic education", "national patriotic education", "national consciousness", "local history", "musical local history", "art local history" in pedagogical artistic content (multidisciplinary vector) are analysed. No shared understanding of the term "patriotism" and derivatives of the word is determined. Scientists have the similar ideas according to the structure and components of this integral phenomenon. The article determines an educational potential of local history in particular the art local history as a method of national patriotic education of future teachers of music.

Scientific novelty is in analyzing the systematization of encyclopedic reference, psychological and pedagogical, public regulations sources and synthesizing of data obtained on the content of structure and essence of the term "patriotism" and national patriotic education. The focus is to release the power of educational potential of local history in particular art local history as a method of national patriotic education of future teachers of music.

Practical significance. The usefulness of the author's course "Musical local studies of Rivne region" for the teacher's training of all art specialities as a method of national patriotic education was proved.

Keywords: patriotism; patriotic education; national patriotic education; national consciousness; local history; musical local history; art local history.

П остановка проблеми. На тлі серйозних суспільно-політичних та соціально-культурних трансформацій в незалежній Україні гостро постає питання збереження та зміцнення української суверенної держави, де особливої актуальності набуває національно-патріотичне виховання молоді, як майбутньої цементуючої основи стійкості й цілісності нашої держави.

В умовах модернізації сучасної української школи, у тому числі і вищої, реалізації завдань реформування освіти, цілком закономірно також виникає потреба пошуку ефективних виховних механізмів, що здатні забезпечити становлення національно свідомих громадян України, патріотів держави. Особливо це питання актуалізується у вищій школі, зокрема у вихованні майбутнього вчителя (зокрема й музичного мистецтва), професійна діяльність якого також значною мірою буде спрямована на патріотичне виховання учнів. 


\begin{abstract}
Аналіз наукових досліджень і публікацій 3 теми дає підстави стверджувати, що питання патріотичного виховання достатньо широко представлені у наукових дослідженнях. Так, теоретичний аспект національно-патріотичного виховання має глибоке коріння у поглядах відомих українських діячів й педагогів минулого: Х. Алчевської, Г. Ващенка, Б. Грінченка, М. Грушевського, М. Драгоманова, О. Духновича, А. Макаренка, І. Огієнка, С. Русової,В. Сухомлинського, К. Ушинського таін., які великого значення надавали вихованню любові до Батьківщини, рідної мови, формуванню національної самосвідомості й гідності, повазі до традицій, історичного минулого. Психологічні основи патріотичного виховання висвітлено упрацях Б. Ананьєва, М. Боришевського, Л. Виготського, Г. Костюка, О. Леонтьєва, О. Петровського та ін. Проблеми національнопатріотичного виховання також стали предметом уваги сучасних вчених: І. Беха, П. Вербицької, О. Гевко, О. Жаровської, К. Журби, М. Качур, Р. Петронговського, А. Погрібного, Ю. Руденка, О. Стьопіної, Г. Філіпчука, К. Чорної, Г. Шевченко та ін.
\end{abstract}

Крім того, увага приділяється і окремим напрямам краєзнавства. Так, історичне краєзнавство Волині досліджували О. Булига, Г. Бухало, Г. Данильчук, В. Данілічева, Б. Прищепа, О. Прищепа, П. Тронько та ін.; літературне краєзнавство Волині постало предметом уваги праць Г. Дем'янчука, I. Нагорної, I. Пащука та ін.; безпосередньо музичний фольклор Волині вивчали В. Ковальчук, В. Павлюк, Б. Столярчук, Н. Супрун, Р. Цапун, С. Шевчук та ін. Однак, питання національно-патріотичного виховання майбутніх педагогів засобами мистецького, зокрема музичного краєзнавства, як цілісного культурного феномену Волинського краю, поки не стало об’єктом спеціального наукового пошуку дослідників.

Мета статті - проаналізувати державні документи щодо національно-патріотичного виховання та теоретично-педагогічні підходи до сутності й змісту понять “патріотизм”, "патріотичне виховання", "національно-патріотичне вихання”, “національна самосвідомість”, “краєзнавство”, “мистецьке краєзнавство”, “музичне краєзнавство” та виявити виховний потенціал мистецького краєзнавства як засобу національно-патріотичного виховання майбутніх педагогів усіх мистецьких спеціальностей.

Виклад основного матеріалу. Сьогодні національно-патріотичне виховання молоді за своїм значенням визначається стратегічним завданням й одним з головних напрямів виховання та має охоплювати серед інших сфер - освіту, науку, культуру, мистецтво, краєзнавство, історію, що відображено у таких державних документах: “Концепція національно-патріотичного виховання дітей і молоді”, “Стратегія національнопатріотичного виховання дітей та молоді на 2016 - 2020 роки", Указ Президента України “Про заходи щодо поліпшення національнопатріотичного виховання дітей та молоді", Закон України "Про освіту", "Національна стратегія розвитку освіти в Україні на період до 2021 року” тощо $[11 ; 12 ; 13 ; 16 ; 17]$.

Так, у Концепції національно-патріотичного виховання дітей і молоді національнопатріотичне виховання визначається як комплексна системна й цілеспрямована діяльність державної влади, освітніх закладів, організацій, сім’ї щодо формування у молоді патріотичноі свідомості, почуття любові до Батьківщини, готовності до захисту національних інтересів, незалежності України тощо [12]. Головною метою національно-патріотичного виховання $\epsilon$ виховання громадянина-патріота України, готового до успадкування культурних, духовних, надбань народу; формування у молоді високої патріотичної свідомості, ціннісного ставлення до українського народу, держави, нації [17]. Мета патріотичного виховання, що спирається на принцип національної спрямованості, полікультурності, історичної пам'яті та ін., реалізується через систему таких виховних завдань: формування у молоді толерантного ставлення до інших народів, культур, традицій; виховання поваги до культурного, історичного минулого України [12].

У Законі України "Про освіту” зазначено, що засадами державної політики у сфері освіти та принципами освітньої діяльності серед інших $\epsilon$ виховання патріотизму, поваги до культурних цінностей, історико-культурних традицій та надбань Українського народу [11].

Основоположною у системі виховання $\epsilon$ національна ідея, що відіграє роль консолідуючого чинника розвитку суспільства й нації. Патріотичне виховання як складова національного передбачає формування патріотичних почуттів, розуміння громадського обов'язку. Національне виховання на культурноісторичному досвіді, традиціях й звичаях рідного народу забезпечує етнізацію молоді як необхідний і невід'ємний складник їхньої соціалізації. Національне виховання є відтворенням як специфічного, самобутнього, що є в кожній нації, так і загальнолюдського, спільного для всіх націй світу $[15,64]$. 


\section{МИСТЕЦЬКЕ КРАЄЗНАВСТВОЯК ЧИННИК НАЦІОНАЛЬНО-ПАТРІОТИЧНОГОВИХОВАННЯ МАЙБУТНІХПЕДАГОГІВ}

Існують різні підходи до визначення поняття “патріотизм”. Патріот у перекладі з мови грецької (patriotes) означає “земляк, співвітчизник”, а патріотизм тлумачиться як любов до батьківщини, відданість народові, готовність на подвиги, жертви заради них [3, 894; 14, 511].

Філософія це поняття визначає як моральнополітичний принцип, соціально-психологічне почуття, що включає в себе любов до Вітчизни, гордість за їі досягнення, повагу до іiї історичного минулого, збереження й опанування національнокультурними традиціями $[19,471]$.

Автор "Українського педагогічного словника" С. Гончаренко тлумачить патріотизм як патріотичні переконання й погляди, соціальноісторичне явище, що виявляється у практичній діяльності, спрямованій на розвиток та захист своєї країни та “одне $з$ найглибших громадянських почуттів, змістом якого є любов до батьківщини, відданість своєму народові, гордість за надбання національної культури" [7, 249].

Суголосно й більш виразно звучить поняття “патріотизм" в “Енциклопедії освіти”, як “суспільний моральний принцип діяльного ставлення до свого народу, що віддзеркалює національну гордість і любов до Вітчизни, громадянську відповідальність за ії долю, а також емоційне підпорядкування особистістю свого життя спільним національним інтересам", що виявляється у готовності захищати Батьківщину [9, 633].

Відомо, ідеї національно-патріотичного виховання утверджували корифеї вітчизняної педагогіки Г. Ващенко, О. Духнович, С. Русова, В. Сухомлинський, К. Ушинський та ін. Так, К. Ушинський стверджував, що кожен народ має власну національну систему виховання, що покликана виховувати носіїв й діячів культури $[15$, 41], а людину, що не знає своєї національної культури називав “людиною без вітчизни” $[15,39]$. Саме виховання патріотичних почуттів, національної гідності, поваги до інших народів О. Духнович вважав першочерговим завданням педагога та школи $[10,90]$. В. Сухомлинський переконував, що сила й ефективність патріотичного виховання визначається тим, наскільки глибоко ідея Батьківщини оволодіває особистістю та наскільки яскраво людина бачить світ і себе очима патріота [18, 224].

На вихованні у молоді почуття патріотизму, як проблеми загальнодержавного масштабу; ролі національної ідеї, як основи патріотичного виховання наголошують І. Бех і К. Чорна, які зазначають, що у центрі виховного патріотичного процесу - особистість дитини, як найвища цінність $[1,16]$. Патріотизм розглядається авторами як компонент структури особистості, суспільна й індивідуальна цінність; любов й турбота про благо Батьківщини, готовність їі захищати та розділити її долю зі своєю $[1,17]$.

Дослідники розрізняють патріотизм особистісний -якстійку характеристику людини, що проявляється в її свідомості, моральних ідеалах й цінностях, у поведінці й вчинках та патріотизм суспільний (на макрорівні) - як частину суспільної свідомості, що проявляється у ціннісному ставленні до свого народу, його національних здобутків, культури, традицій, історичного минулого й сьогоднішньої розбудови держави як єдиної нації [1, 17 - 18].

I. Бех і К. Чорна наголошують на органічному поєднанні патріотизму та етнічної самосвідомості, що базується на етнічній ідентифікації, яка вбирає в себе любов до свого народу; знання й вміння осмислювати його морально-культурні цінності, звичаї, обряди; передбачає систему вчинків, що мотивуються любов’ю, вірою, відповідальністю перед народом. На високому рівні етнічна самосвідомість переростає в національну самосвідомість, яка передбачає ідентифікацію особистості із усім народом України, незалежно від свого етнічного походження $[1,19]$. Патріотизм передбачає любов та знання особливостей своєї “малої Батьківщини” [1, 18], щзо особливо важливо в контексті національно-патріотичного виховання майбутніх педагогів засобами мистецького, зокрема музичного краєзнавства.

Досліджуючи соціально-філософський вимір патріотизму сучасного українського суспільства, Н. Волошина вважає, що патріотизм є елементом системи духовних цінностей людини, соціальнопсихологічною якістю, що формується, розвивається або втрачається під впливом соціуму й виступає гарантом збереження самобутності й культурної своєрідності українського суспільства, його єднання й гармонізації. Авторка також зауважує, що ядром та основною складовою патріотизму є любов до малої й великої Батьківщини, яка формується під впливом соціальних чинників [6, 12 - 14].

Як складову громадянського виховання, громадянське почуття, змістом якого є любов до Батьківщини, усвідомлення причетності до історії, традицій та культури свого народу, розкриває поняття “патріотизм” Н. Волкова. Вчена наголошує, що виховання має бути спрямованим на розвиток патріотизму, культури міжетнічних відносин, а також національної самосвідомості, яка грунтується на національній ідентифікації (ототожненні), вбирає в себе вміння осмислювати морально-культурні цінності, історію, звичаї, 
обряди та передбачає “усвідомлення себе часткою національної (етнічної) спільноти, носієм національних (етнічних) цінностей” [5, 110 - 111].

В. Кузь, Ю. Руденко, 3. Сергійчук національну самосвідомість називають основним компонентом духовного світу особистості, що несе усвідомлення себе представником певної нації, носієм національної культури, історії [15, 38] та зазначають: чим вища національна самосвідомість, тим глибшою є любов до свого народу, шана до культури інших народів. Патріотизм науковці тлумачать як комплексну якість особистості, що має історичний, суспільно-політичний, національний характер; зароджується з любові до матері, мови, культури та формується засобами народознавства [15, 39].

Різні погляди існують й на різновиди патріотизму. Так, О. Вишневський виділяє їх три: етнічний патріотизм, що грунтується на почутті власної причетності до свого народу, культури, мистецтва, історії тощо; територіальний патріотизм, який грунтується на любові до місцевості, де народилася людина та набуває особливого значення у свідомості представників національних меншин; державницький патріотизм, як досягнення державницького почуття, світогляду й самовизначення [4, 152].

I. Бех і К. Чорна акцентують увагу на важливості формування у свідомості молоді не природовідповідного патріотизму, як первинної й базової психологічної прихильності людини до своєї нації, що виражається у їі належності до родинних зв'язків, звички до географічного ландшафту тощо, а духовно осмисленого, рефлексивного патріотизму, який би поєднував любов до своєї нації, Вітчизни з почуттям поваги до інших народів [1, 21 - 22].

Вчені зазначають, що чимало науковців у проблемі формування патріотизму виокремлюють геоиентричний (як пріоритетне духовне служіння Батьківщині), соціочееттричний (грунтується на належності до єдиного соціуму, держави) i антропоцентричний (основою якого $\epsilon$ переконання, що суб'єктом - носієм патріотизму в соціумі є особистість) підходи та підтримують останній з них, як такий, що визначає первинність прав людини, визнає існуючу в світі різноманітність інтересів, народів і тому $є$ важливим у вирішенні проблем на регіональному рівні $[1,22-24]$.

Український педагог Г. Ващенко виділяв патріотизм стихійний - як неусвідомлену любов до рідної природи, звичаїв, традицій, мови та свідомий - як такий, що не обмежується лише пасивною любов'ю до свого краю, народу, культури, історії, а спрямовує сили на захист Батьківщини [2, 67].

Відтак, виховання патріотизму, національної самосвідомості, відродження історичної пам'яті, збереження культурних народних традицій починається із знання про рідний край, що передаються 3 покоління в покоління через народну пісню, звичаї, рідну мову. Вивчення культури рідного краю пробуджує відданість Вітчизні та повагу не лише до свого народу, а й до інших етносів, народів, що проживають в Україні. Тому важливе місце у вирішенні завдань національно-патріотичного виховання належить краєзнавству, зокрема мистецькому.

Краєзнавство, поєднуючи минуле, сучасне й майбутнє, досліджує пракоріння української духовності, ментальності, зберігає історичний досвід поколінь. Пізнання культури своєї “малої Батьківщини” формує уявлення про долю усієї нації; лише через регіональний патріотизм виростає патріотизм всеукраїнський. Мистецьке краєзнавство, розподіляючись на музичне, хореографічне, театральне тощо вивчає діяльність й творчість діячів культури та мистецтва. Сутність краєзнавства музичного, як складника мистецького краєзнавства, що входить до системи краєзнавчих наук, визначається як вивчення музичної культури регіону, області, міста з метою виявлення її специфіки, закономірностей, функціонування, розвитку [8, 124].

Отже, актуальність введення курсу “Музичне краєзнавство Рівненщини" до підготовки педагогів-музикантів у закладах вищої освіти визначається стратегічними державними завданнями щодо інтенсифікації національнопатріотичного виховання молоді.

3міст курсу, зосереджуючись на музичній складовій культури краю охоплює й інші види мистецтва - образотворче, сценічні мистецтва (театр, хореографію), що спирається на цілісність художньої культури як духовно-естетичного феномена. Мета курсу - вивчення музичної культури Рівненщини як історико-етнографічного регіону Волині, що розвивався у взаємодії культур різних етносів, проживаючих на території краю та формування у студентів системи професійної компетентності як у майбутніх музикантівпедагогів, дослідників, пропагандистів культури рідного краю. Навчально-виховними завданнями курсу є: поглиблення у студентів знань про музичну культуру краю; виховання патріотизму, національної свідомості та ціннісного ставлення до мистецтва краю; формування дослідницьких умінь у практичній краєзнавчо-пошуковій діяльності; виховання потреби та здатності до 
збереження й пропаганди культурних традицій краю в майбутній педагогічній діяльності [8].

Висновки. Узагальнюючи проведений аналіз наукових джерел, у педагогічно-мистецькому контексті патріотизм розуміємо як стійкий компонент системи духовно-культурних цінностей людини, ядром якого $є$ любов і знання своєї малої й великої Батьківщини, її традицій й звичаїв, зокрема мистецьких, що характеризує ціннісне ставлення особистості до Вітчизни в єдності етнічно-культурного й національно-громадянського аспектів, виявляється в культуротворчій діяльності та $€$ гарантом збереження культурної самобутності через етнічну самосвідомість.

Справжній патріотизм виростає 3 любові до рідного краю, формується на народних традиціях, звичаях. Введення дисципліни “Музичне краєзнавство Рівненщини" у навчальну програму закладів вищої освіти до підготовки студентів усіх мистецьких спеціальностей визначається нагальністю державних завдань щодо інтенсифікації національно-патріотичного виховання молоді та сприятиме розвитку національної музичної культури.

\section{ЛІТЕРАТУРА}

1. Бех І. Д., Чорна К. І. Національна ідея в становленні громадянина-патріота України: (Програмно-виховний контекст). Черкаси, 2010.40 с.

2. Ващенко Г. Вибрані педагогічні твори. Дрогобич: Відродження, 1997. 214 с.

3. Великий тлумачний словник сучасної української мови / Гол. ред. В. Т. Булес. Київ, 2004. $1440 \mathrm{c}$.

4. Вишневський О. Теоретичні основи сучасної української педагогіки: Посібник для студ. вищих навч. закл. Вид. 2-ге, перероб., доп. Дрогобич, $2006.326 \mathrm{c}$.

5. Волкова Н. П. Педагогіка : Навч. посіб. Вид. 2-ге, перероб., доп. Київ, 2007. 618 с.

6. Волошина Н. М. Соціально-філософський вимір патріотизму сучасного українського суспільства : автореф. дис. ... канд. філос. наук : 09.00.03. Київ, 2010. 22 с.

7. Гончаренко С. Український педагогічний словник. Київ, 1997. 376 с.

8. Дикало В. Музичне краєзнавство Рівненщини як навчальний курс: до постановки проблеми. Нова педагогічна думка : наук.-метод. журнал, 2016. № 2 (86). C. 124-128.

9. Енциклопедія освіти / АПН України; Голов. ред. В. Г. Кремень. Київ, 2008. 1040 с.

10. Жупанин С. I. Народознавча педагогіка Олександра Духновича. Рідна шикола, 1991. № 910. С. 89-91.
11. Закон України "Про освіту” № 2145-VIII від 05.009.2017 p. URL: https://zakon.rada.gov.ua/ laws/show/2145-19.

12. Концепція національно-патріотичного виховання дітей і молоді. Заходи щодо реалізації Концепції національно-патріотичного виховання дітей і молоді та методичні рекомендації щодо національно-патріотичного виховання у загальноосвітніх навчальних закладах (Наказ МОН України від 16.06.2015 р. № 641) [Електронний ресурс]. URL: http://osvita.ua/ legislation/Ser osv/47154/.

13. Національна стратегія розвитку освіти в Україні на період до 2021 року від 25.06.2013 № 344/ 2013. URL: http://zakon3.rada.gov.ua/laws/show/344/ $\underline{2013}$.

14. Нечволод Л. І. Сучасний словник іншомовних слів. Харків: ТОРСІНГ ПЛЮС, 2008. 768 с.

15. Основи національного виховання: концептуальні положення / В. Г. Кузь, Ю. Д. Руденко, 3. О. Сергійчук та ін. Умань, 1993. 112 с.

16. Про заходи щодо поліпшення національнопатріотичного виховання дітей та молоді: Указ Президента України від 12.06.2015 p. № 334. URL: http://zakon4.rada.gov.ua/laws/show/334/2015.

17. Стратегія національно-патріотичного виховання дітей та молоді на 2016-2020 роки: Указ Президента України від 13.10.2015 р. № 580/2015. URL: http://www.president.gov.ua/documents/ 5802015-19494.

18. Сухомлинский В. А. О воспитании / Сост. С. Соловейчик. Изд. 2-е. Москва, 1975. 272 с.

19. Філософський енциклопедичний словник / НАН України, Ін-т філософії ім. Г. С. Сковороди; Ред. кол. В. І Шинкарук (голова) та ін. Київ, 2002. $744 \mathrm{c.}$

\section{REFERENCES}

1. Bekh, I. D. \& Chorna, K. I. (2010). Natsionalna ideia $v$ stanovlenni hromadianynapatriota Ukrainy: (Prohramno-vykhovnyi kontekst) [The National Idea in Becoming a Patriot Citizen of Ukraine: (Program-Educational Context)]. Cherkasy, 40 p. [in Ukrainian].

2. Vashchenko, H. (1997). Vybrani pedahohichni tvory [Selected pedagogical works]. Drohobych, 214 p. [in Ukrainian].

3. Bules, V. T. (Ed.). (2004). Velykyi tlumachnyi slovnyk suchasnoi ukrainskoi movy [A great explanatory dictionary of modern Ukrainian]. Kyiv, 1440 p. [in Ukrainian].

4. Vyshnevskyi, O. (2006). Teoretychni osnovy suchasnoi ukrainskoi pedahohiky [Theoretical foundations of modern Ukrainian pedagogy]. Drohobych, 326 p. [in Ukrainian]. 
5. Volkova, N. P. (2007). Pedahohika [Pedagogy]. Kyiv, 618 p. [in Ukrainian].

6. Voloshyna, N. M. (2010). Sotsialno-filosofskyi vymir patriotyzmu suchasnoho ukrainskoho suspilstva [Socio-philosophical dimension of patriotism of modern Ukrainian society]. Extended abstract of Candidate's thesis. Kyiv, 22 p. [in Ukrainian].

7. Honcharenko, S. (1997). Ukrainskyi pedahohichnyi slovnyk [Ukrainian Pedagogical Dictionary]. Kyiv, 376 p. [in Ukrainian].

8. Dykalo, V. (2016). Muzychne kraieznavstvo Rivnenshchyny yak navchalnyi kurs: do postanovky problemy [Musical History of the Rivne Region as a Training Course: Before the Problem]. New pedagogical thought, Vol. 2 (86), pp. 124-128. [in Ukrainian].

9. Kremen, V. H. (Ed.). (2008). Entsyklopediia osvity [Encyclopedia of Education]. Kyiv,1040 p. [in Ukrainian].

10. Zhupanyn, S. I. (1991). Narodoznavcha pedahohika Oleksandra Dukhnovycha [Ethnological pedagogy of Alexander Duchnovich]. Home school, Vol. 9-10, pp. 89-91. [in Ukrainian].

11. Zakon Ukrainy "Pro osvitu" [Law of Ukraine "On Education"]. Available at: https:// zakon.rada.gov.ua/laws/show/2145-19. [in Ukrainian].

12. Kontseptsiia natsionalno-patriotychnoho vykhovannia ditei i molodi, Zakhody shchodo realizatsii Kontseptsii natsionalno-patriotychnoho vykhovannia ditei $\mathrm{i}$ molodi ta metodychni rekomendatsii shchodo natsionalno-patriotychnoho vykhovannia u zahalnoosvitnikh navchalnykh zakladakh [Concept of national patriotic upbringing of children and youth, Measures to implement the
Concept of national patriotic upbringing of children and young people and methodical recommendations on national patriotic upbringing in general educational institutions]. Available at: http://osvita.ua/legislation/ Ser osv/47154/. [in Ukrainian].

13. Natsionalna stratehiia rozvytku osvity v Ukraini na period do 2021 roku [National Strategy for the Development of Education in Ukraine until 2021] Available at: http://zakon3.rada.gov.ua/laws/show/ 344/2013. [in Ukrainian].

14. Nechvolod, L. I. (2008). Suchasnyi slovnyk inshomovnykh sliv [Modern dictionary of foreign words]. Kharkiv, 768 p. [in Ukrainian].

15. Kuz, V. H., Rudenko, Yu. D., Serhiichuk Z. O. (1993). Osnovy natsionalnoho vykhovannia: kontseptualni polozhennia [Fundamentals of National Education: Conceptual Provisions]. Uman, 112 p. [in Ukrainian].

16. Pro zakhody shchodo polipshennia natsionalnopatriotychnoho vykhovannia ditei ta molodi [On Measures to Improve National-Patriotic Education of Children and Youth]. Available at: http:// zakon4.rada.gov.ua/laws/show/334/2015.

17. Stratehiia natsionalno-patriotychnoho vykhovannia ditei ta molodi na 2016-2020 roky [Strategy of national patriotic education of children and youth for 2016-2020]. Available at: http:// www.president.gov.ua/documents/5802015-19494.

18. Soloveichyk, S. (1975). Sukhomlynskyi V. A. $O$ vospitanii [Sukhomlinsky V. A. About education] Moscov, 272 p. [in Russian].

19. Shynkaruk, V. I. (2002). Filosofskyi entsyklopedychnyi slovnyk [Encyclopedic Dictionary of Philosophy]. Kyiv, 744 p. [in Ukrainian].

Стаття надійшла до редакції 31.10.2019

\section{G58089}

“Написане повинне бути легке для читання і легковимовне, що одне і те ж”.

Apicmoтeль

давньогреиький боілособ

“Виховання, головним чином, повинно засіяти наші серия корисними для індивіда і суспільства звичқами".

Клод Адріан Тельвеиій франиузький хітератор, фбілособ

"Мистеитво виховання має ту особливість, що майже всім воно здається справою знайомою й зрозумілюю, а іншим - навіть легқою, $і$ тим зрозумілішою $і$ легшою здається воно, чим менше людина з ним знайома теоретично і практично".

Костянтин УУиинський педагог українського походження

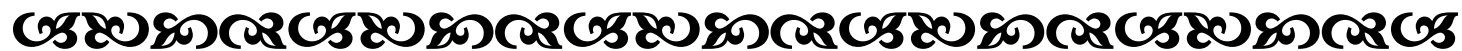

